\title{
Study of Relationship between the Profile of Farm Women Labourer and Drudgery Involved in Farm Operations
}

\author{
J.V. Ekale, M.V. Kulkarni, Pravin N. Chavhan* and H.S. Dudhal
}

Extension Education, Department of Extension, VNMKV, Parbhani, Maharashtra, India

*Corresponding author

\begin{tabular}{|l|}
\hline Ke y w o r d s \\
$\begin{array}{l}\text { Drudgery, } \\
\text { Relationship, Farm } \\
\text { operations, Women } \\
\text { labourer etc. }\end{array}$ \\
\hline Article Info \\
\hline $\begin{array}{l}\text { Accepted: } \\
\text { 15 January } 2018 \\
\text { Available Online: } \\
\text { 10 February } 2018\end{array}$ \\
\hline
\end{tabular}

\section{Introduction}

Women play a significant and crucial role in the agricultural operations. They are the pivot around whom the family, society and whole community move. In India, nearly 75 per cent of the women hail from rural areas where the impact of science and technology on daily life is limited. Further, most of the farm women have extremely busy schedule of work on farm and related activities besides their exclusive involvement in domestic chores. Moreover women perform the multiple tasks in a traditional manner due to limited
The present study was conducted in Parbhani district from Marathwada region of Maharashtra State. For this study, a random lottery method was used to select district and two talukas, from each taluka six villages were randomly selected. 10 respondents from each village were randomly selected. Total 120 respondents selected from villages, they were interviewed, personally to collect the data with the help of structured interview schedule. Ex-Post Facto research design was used for the research study. The collected data were processed and statistically analyzed. The coefficient of correlation was used to find out the relationship between the selected independent and dependent variables. As regards, the relationship of profile of women labourers, namely wages, family size, working condition, family type, distance of work place from residence, pattern of employment, duration of employment and age found to have positive and highly significant correlation with drudgery and family annual income had negatively significant correlation with drudgery. Whereas, education, marital status, social participation, and working hours did not show any significant correlation with drudgery in activities performed by women labourer in farm operations. 
responsibility leaving women's burden unrelieved or even increased. Extension workers, almost exclusively males, aim their advice at men. Hence, farm women being generally illiterate and ignorant due to lack of knowledge, exposure, etc. spend long hours, much effort and labour in repetitive operations resulting in fatigue and drudgery. Drudgery is generally conceived as physical and mental strain, fatigue, monotony and hardships experienced while doing a job. It is certain, that if appropriate drudgery reducing farmstead implements are made available to the rural women, these would contribute to reduction in drudgery, increase capability, productivity and consequently the greater workload thereby improved efficiency. Many agricultural operations and household activities performed by women involve a lot of physical strain, which create serious health problems in the long run. Since they are overburdened with so much work both on farm and home, there is chance of neglecting their health. Thus, the burden shared by women for the socio-economic development is twofold, one on the domestic front and the other on the economic front. The difficulties of getting drinking water, fuel for cooking, health services etc. stand obstacles to run their domestic front smoothly. Besides, they have to adjust in a number of adverse situations while performing economic activities outside their home.

According to an International Labour Organization (1964) estimation, women, perform one third of the world's counted labour. Thus it is a fact that their contribution to the economic growth of the society is quite substantial. The vast majority of rural women in the unorganized sector are landless; they work in the field performing a variety of farming operations like sowing, transplanting, weeding, harvesting, threshing, winnowing, storing and processing the grain. In addition they bear the burden of bearing and rearing children, collecting and fetching water, gathering firewood for cooking and cleaning activities, which consume much time and energy. Although women work for longer hours and contribute substantially to the family income they are not recognized as workers, either by themselves or the data collecting agencies and the government.

\section{Materials and Methods}

The present study was conducted in Parbhani district from Marathwada region of Maharashtra State. For this study, A randomly lottery method was used to select district and two talukas, from each taluka six villages were randomly selected. 10 respondents from each village were randomly selected. Total 120 respondents selected from villages, they were interviewed, personally to collect the data with the help of structured interview schedule. The Ex-Post Facto research design was used for the research study. The collected data were processed and statistically analyzed with the help of frequency, percentage, mean, standard deviation, correlation coefficient and multiple regression.

\section{Results and Discussion}

Relationship between profile of women labourer and their drudgery involved in performing farm operations

It is observed from Table 1, that the results of correlation coefficient ( $r$ ) showed as below

\section{Age and drudgery}

The data of results of the present study clearly explained that the correlation of coefficient showed positive and highly significant $(\mathrm{r}=0.568)$ relationship between age and drudgery. It can be visualize from the data that age of the women was positively correlated with drudgery. As age increases the extent of 
drudgery also increases. The young women have more physical strength to perform farm operations.

The findings were supported by Kohale (1991), Bhangey (1999), Chayal and Dhaka (2010), Khan et al., (2012), Wankhade et al., (2015).

\section{Education and drudgery}

It was found that education did not show any significant correlation with drudgery. There was no influence of education on drudgery because of farm operations are labourious work, it involves drudgery in the form of physical strain, moderate fatigue.

The findings were supported by Patel et al., (1995), Kulkarni (1998), Jyostna Tathod (2000), Wankhade et al., (2015).

\section{Marital status}

The results of the present study clearly explained that the correlation of coefficient did not show any significant correlation between marital status and drudgery. There was no correlation between marital status and drudgery because of in every house women must need to perform household works either she is married or not.

The findings were supported by Jyostna Tathod (2000), Wankhade et al., (2015).

\section{Family size}

The results of the present study clearly explained that the correlation of coefficient showed positive and highly significant $(\mathrm{r}=0.683)$ relationship between family size and drudgery. It was concluded from above result that as the members of family increase the workload also increases, because women labourer has to look after all family members, prepare their meals, wash cloths care of children etc., perform other household work in addition to she has to go for the work at farm in time. The basic needs of family increases, hence women need to work for long duration in a year to earn more wages and fulfil family needs. Therefore, there was positive relation between family size and drudgery.

The findings are in line with Jyostna Tathod (2000), Wankhade et al., (2015).

\section{Family type}

It was noticed in the results of present study that the correlation coefficient showed positive and highly significant $(r=0.335)$ relationship between family type and drudgery. It was concluded from above result that joint family type results in more drudgery in the farm work because women labourer has to look after all family members, prepare their meals, wash cloths care of children etc., perform other household work in addition to she has to go for the work at farm in time. So, ultimately she has to exert more inside and outside the house.

The findings are in line with Wankhade et al., (2015).

\section{Family annual income}

The results of the present study clearly explained that the correlation coefficient showed negative and significant $(\mathrm{r}=-0.261)$ relationship between family annual income and drudgery. It was concluded from above result that as family annual income decreased, the drudgery level increased due to if family has get sufficient income, there is less workload to women. There is no need to work for long duration.

The similar findings were supported by Tikhile (2001), Wankhade et al., (2015). 
Table.1 Relationship between profiles of women labourers with their drudgery involved in farm operations

\begin{tabular}{|l|l|l|}
\hline Sr. No. & Profile & 'r' values \\
\hline 1. & Age & $0.568^{* *}$ \\
\hline 2. & Education & $-0.014^{\mathrm{NS}}$ \\
\hline 3 & Marital status & $0.009^{\mathrm{NS}}$ \\
\hline 4. & Family size & $0.683^{* *}$ \\
\hline 5. & Family type & $0.335^{* *}$ \\
\hline 6. & Family annual income & $-0.261^{* *}$ \\
\hline 7. & Working conditions & $0.420^{* *}$ \\
\hline 8. & Social participation & $0.111^{\mathrm{NS}}$ \\
\hline 9. & Pattern of employment & $0.503^{* *}$ \\
\hline 10. & Duration of employment & $0.207^{*}$ \\
\hline 11. & Distance of work place from residence & $0.540^{* *}$ \\
\hline 12. & Wages received & $0.644^{* *}$ \\
\hline 13. & Working hours & $0.047^{\mathrm{NS}}$ \\
\hline **Significant at 0.01 level of probability & \\
*Significant at 0.05 level of probability & \\
\hline
\end{tabular}

\section{Working conditions}

It was noticed in the results of present study that the correlation coefficient showed positive and highly significant $(\mathrm{r}=0.420)$ relationship between working condition and drudgery. It was concluded from above result that as family annual income decreased, the drudgery level increased due to if family has get sufficient income, there is less workload to women. There is no need to work for long duration.

The similar findings were supported by Tikhile (2001), Wankhade et al., (2015).

\section{Social participation}

It was found that social participation did not show any significant correlation with drudgery. Working condition of women labourer will result in more drudgery involved as it had to be performed in odd situation and there is no improved implement to perform them hence, physical strain was more and so the results are justified i.e. working condition is positively correlated with drudgery. The findings in line with Jyostna Tathod (2000), Wankhade et al., (2015).

\section{Pattern of employment}

It was noticed in the results of present study that the correlation coefficient showed positive and highly significant $(\mathrm{r}=0.503)$ relationship between pattern of employment and drudgery. The probable reason might be that respondents being farm women, so always engaged in farming and home activities. From the above result it was concluded that whether women has social participation or not there is no influence on drudgery. Because they must be perform both household and agricultural activities.

The findings are in line with Wankhade et al., (2015).

\section{Duration of employment}

It was noticed in the results of present study that the correlation coefficient showed 
positive and significant $(\mathrm{r}=0.207)$ relationship between duration of employment and drudgery. The probable reason might be that pattern of employment of women labourer will result in more drudgery involved as it had to be performed in odd situation and there is no improved implement to perform them hence, physical strain was more and so the results are justified i.e. pattern of employment is positively correlated with drudgery.

The similar findings were supported by Wankhade et al., (2015).

\section{Distance of work place from residence}

It was noticed in the results of present study that the correlation coefficient showed positive and highly significant $(r=0.540)$ relationship between distance of work place from residence and drudgery. It was revealed from result that longer the distance of work place from the residence of women labourer will result in more physical exertion, fatigue and more time will be required for attending the work and because of this women labourer will feel the more drudging and so the results are justified i.e. the distance of work place is positively correlated with drudgery.

The findings in line with Jyostna Tathod (2000) and Wankhade et al., (2015).

\section{Wages received}

It was noticed in the results of present study that the correlation coefficient showed positive and highly significant $(r=0.644)$ relationship between wages received and drudgery. It was concluded from above result that as duration of employment increases the drudgery also increases. The work in farm is seasonal and hence, generally the workforce is employed as seasonal. Therefore, duration of employment showed positive relationship with drudgery.
The similar findings were supported by Zend (2009) and Wankhade et al., (2015).

\section{Working hours}

It was found that working hours did not show any significant correlation with drudgery. It was revealed from result that longer the distance of work place from the residence of women labourer will result in more physical exertion, fatigue and more time will be required for attending the work and because of this women labourer will feel the more drudging and so the results are justified i.e. the distance of work place is positively correlated with drudgery.

The findings in line with Jyostna Tathod (2000) and Wankhade et al., (2015).

As regards, the relationship of profile of women labourers, namely wages, family size, working condition, family type, distance of work place from residence, pattern of employment, duration of employment and age found to have positive and highly significant correlation with drudgery and family annual income had negatively significant correlation with drudgery. Whereas, education, marital status, social participation, and working hours did not show any significant correlation with drudgery in activities performed by women labourer in farm operations.

It was found that farm women labourer had high drudgery in almost all the farm operations. So, as to reduce drudgery, on the strength of findings it is suggested that there working conditions especially in respect of health and hygienic be taken care of and wages for their work should be increased. Regularly their medical check-up be undertaken to minimize the effect of drudgery. Developed machinery or equipments should be provide to minimize physical strain or reduce drudgery in respect 
of threshing, weeding, sowing, cutting of standing crop, picking of matured pod, winnowing etc. It will help to reduce drudgery which will ultimately improve work satisfaction.

\section{References}

Bhangey, V. K., 1999. Role of women in agriculture operations. M.Sc. Thesis (Unpub.) Dr. PDKV, Akola.

Chayal. K and B. L. Dhaka 2010. Analysis of role performance of women in farm activities. Indian Res. J. Ext.Edu. 10 (2): 109-112.

International Labour Organization, 1964. Maximum Permissible loads to be carried by one worker. Occupational safety and health series No. 5 .

Jyotsna, K. T. 2000. Work satisfaction and drudgery faced by women workers of cotton ginning factory. M.Sc. Thesis (Unpub.) Dr. PDKV, Akola.

Khan, M., M. Sajjad, B. Hameed, M. N. Khan and A. V. Jan 2012. Participation of women in agriculture activities in district Peshawar. Sarhad J. Agric. Vol.28: 121-127.

Kohale, S. B., 1991. The role of farm women in decision making of farm and home aspect in kamptee black of Nagpur district (unpub) M.sc. Thesis Dr. PDKV, Akola.

Kulkarni, R. R.1998. Perception of drudgery by farm women. Maharashtra J. Exten. Educ. XVII; 288-290.

Tikhile, H. S., 2001. Role of tribal women in Farm operations. M.Sc. Thesis (Unpub.) Dr. PDKV, Akola.

Wankhade P. P., D. M. Mankar, N. M. Kale and Y. B. Shambharkar, 2015. Drudgery perceived by Women Labourers in Farm Operations, Indian Res. J. Ext. Edu. 15 (3): 85-90.

Zend, J. P., S. H. Umrikar and D. Murli 2009. Paricipation, awareness and health problem of women in agriculture. Asian journal of home science. Vol.4, (1): 119-122.

\section{How to cite this article:}

Ekale, J.V., M.V. Kulkarni, Pravin N. Chavhan and Dudhal, H.S. 2018. Study of Relationship between the Profile of Farm Women Labourer and Drudgery Involved in Farm Operations. Int.J.Curr.Microbiol.App.Sci. 7(02): 1411-1416. doi: https://doi.org/10.20546/ijcmas.2018.702.170 